\title{
Cell cycle-regulated nuclear localization of MCM2 and MCM3, which are required for the initiation of DNA synthesis at chromosomal replication origins in yeast
}

\author{
Hong Yan, ${ }^{1}$ A. Margaret Merchant, and Bik K.Tye \\ Section of Biochemistry, Molecular and Cell Biology, Cornell University, Ithaca, New York 14853 USA
}

\begin{abstract}
MCM2 and MCM3 are two genetically interacting and structurally related proteins essential for growth in Saccharomyces cerevisiae. Mutants defective in these proteins affect the stability of minichromosomes in general, but the severity of the defect is dependent on the autonomously replicating sequence (ARS) that drives the replication of that plasmid. In this paper we show by two-dimensional gel electrophoresis that the initiation of DNA synthesis at chromosomal replication origins is also reduced in frequency in these mutants. We show further that the nuclear and subnuclear localizations of the MCM2 and MCM3 proteins are temporally regulated with respect to the cell cycle. These proteins enter the nucleus at the end of mitosis, persist there throughout $G_{1}$ phase, and disappear from it at the beginning of $S$ phase. Once inside the nucleus, a fraction of the MCM2 and MCM3 proteins becomes tightly associated with DNA. The association of MCM2 and MCM3 with chromatin presumably leads to the initiation of DNA synthesis, and their subsequent disappearance from the nucleus presumably prevents reinitiation of DNA synthesis at replication origins. This temporally and spatially restricted localization of MCM2 and MCM3 in the nucleus may serve to ensure that DNA replication occurs once and only once per cell cycle.
\end{abstract}

[Key Words: MCM2; MCM3; S. cerevisiae; nuclear localization; initiation of DNA synthesis; DNA replication; licensing factors]

Received July 13, 1993; revised version accepted August 24, 1993.

Regulation of DNA replication in eukaryotes is dovetailed with stages of the cell cycle. In each cell cycle, (1) replication occurs only during S phase, (2) chromosomal re-replication is prevented, (3) mitosis is delayed until replication is completed, and (4) the re-replication block is removed before the next $S$ phase. The coupling between completion of DNA replication and mitosis is relatively well understood. Replicating DNA sends out a negative signal that suppresses the activation of MPF, the mitosis (or maturation) promoting factor (Dasso and Newport 1990; Smythe and Newport 1992). In contrast, little is known about other mechanisms that coordinate DNA replication with the cell cycle.

Using Xenopus egg extracts, Blow and Laskey (1988) found that to get a second round of replication, nuclei either have to go through mitosis, during which the nuclear envelope breaks down and reassembles, or be permeabilized with nonionic detergents. This observation suggests the existence of an essential replication factor, called licensing factor, which is destroyed immediately after replication initiation and which cannot gain access

\footnotetext{
${ }^{1}$ Present address: Department of Biology, University of California, San Diego, California 92093 USA.
}

into the nucleus unless the nuclear envelope is perturbed. In this way, cells can effectively block re-replication of their genome and then erase the block by going through mitosis. The concept of a licensing factor can easily explain the results of earlier cell fusion studies that $G_{1}$ nuclei, but not $G_{2}$ nuclei, can initiate DNA replication when fused with S cells (Rao and Johnson 1970). However, this hypothesis has two drawbacks. First, the molecular nature of such a licensing factor, if it exists, has yet to be defined. Second, in lower eukaryotes, such as the budding yeast Saccharomyces cerevisiae, the nuclear membrane does not break down during mitosis.

$S$. cerevisiae offers an excellent model system for studying DNA replication and its control in eukaryotes. Replication origins isolated from their native chromosomes can function as autonomously replicating sequences (ARSs) when cloned in plasmids (Brewer and Fangman 1987; Huberman et al. 1988). We have identified a number of mutants, called $\mathrm{mcm}$, that appear to affect the efficient function of ARSs (Maine et al. 1984; Gibson et al. 1990). In these mutants, the stability of minichromosomes is affected to dramatically different degrees, depending on which ARS is present on the minichromosome. These differences in stability suggest that 
the action of the MCM proteins are targeted at ARSs (Maine et al. 1984; Gibson et al. 1990; Yan et al. 1991; Chen et al. 1992). In addition, in some of these mutants, such as $m c m 2-1$, the instability of minichromosomes has been shown to be the result of nonreplication rather than nondisjunction (Sinha et al. 1986). Although instability of plasmids is a general property of mutants defective in DNA metabolism or chromosome segregation, this ARS-specific destabilization of plasmids is unique only to the $\mathrm{mcm}$ mutants (Elble and Tye 1992). Other phenotypes associated with these mutants include increased rates of mitotic recombination and chromosome loss (Sinha et al. 1986; Gibson et al. 1990; Hennessy et al. 1990; Elble and Tye 1992), consistent with defects in DNA replication.

Three of the MCM gene products, MCM2, MCM3, and MCM5, appear to be structurally and functionally related. Sequence analysis revealed that MCM2 and MCM3 share extensive amino acid sequence similarities with each other (Yan et al. 1991) and with another yeast protein, CDC46, which is believed to play an important role in the early steps of DNA replication (Hennessy et al. 1990, 1991). Complementation and genetic linkage analyses indicated that MCM5 is identical to CDC46 (Chen et al. 1992). Sequence similarities within this protein family, designated MCM2-3-5, concentrate in three regions. The central and most extensive region contains $\sim 60 \%$ identity and $\sim 80 \%$ similarity over $\sim 200$ amino acids (Chen et al. 1992). Although these proteins are functionally and structurally related, they cannot functionally substitute one another. Each one of them is essential for cell growth (Yan et al. 1991). Homologs of MCM3 and CDC46/MCM5 have been identified in other organisms. The fission yeast Schizosaccharomyces pombe contains a CDC46/MCM5 homolog, Nda4, mutations in which lead to nuclear division arrest (M. Yanagida, pers. comm.). Mammalian cells contain an MCM3 homolog, the Pl protein, which was identified by its copurification with the polymerase $\alpha$ holoenzyme (Thommes et al. 1992). Recently, Coxon et al. (1992) reported that Cdc21 of $S$. pombe, which has an execution point before the hydroxyurea (HU) block, represents a new member of this family of proteins. It appears that this family of replication proteins may be conserved in all eukaryotes.

The $c d c 46$ mutants were originally identified as allelespecific suppressors of $c d c 45$ and $c d c 54$ mutants that arrest at the $G_{1} / S$ transition of the cell cycle (Moir et al. 1982). Interestingly, $c d c 46$ mutants also exhibit a $G_{1} / S$ arrest phenotype. Furthermore, like other $\mathrm{mcm}$ mutants, cdc $46 / \mathrm{mcm} 5$ mutants are defective in minichromosome maintenance in an ARS-specific manner (Chen et al. 1992). However, the most suggestive evidence that CDC46/MCM5 plays a role in the regulation of replication initiation stems from its cell cycle-dependent subcellular localization pattern. It enters the nucleus at the end of mitosis, remains there throughout the $G_{1}$ phase, but becomes predominantly cytoplasmic around the $\mathrm{G}_{1} / \mathrm{S}$ transition point (Hennessy et al. 1990). The duration of the nuclear presence of CDC46/MCM5 in yeast coincides with that of the hypothetical licensing factor in higher eukaryotes, that is, from nuclear envelope dissassembly to $G_{1} / S$ transition.

In this paper we show that defects in the MCM2 and MCM3 proteins lead to defects in the initiation of DNA synthesis at chromosomal replication origins. We show that the periodic nuclear import of these proteins occurs with a timing that is synchronous with CDC46 and coincident with the cyclical breakdown of the nuclear envelope in higher eukaryotes.

\section{Results \\ MCM2 and MCM3 are required for the initiation of DNA synthesis at chromosomal replication origins}

The $\mathrm{mcm}$ mutants affect the stability of minichromosomes in an ARS-specific manner. For example, mcm2-1 destabilizes the minichromosome YCpl, which carries ARS1 but has no effect on the stability of YCp121, which carries ARS121 (Fig. 1A). Similarly, mcm3-1 has a much more dramatic effect on YCpl than YCp121. This ARSdependent minichromosome maintenance defect of the mcm mutants suggests that these mutants are defective in the initiation of DNA synthesis at ARSs. To show that this defect is not a phenomenon observed only in plasmid replication, we examined the effect of the mcm2-1 and mcm3-1 mutations on the initiation of DNA synthesis at two chromosomal replication origins by two-dimensional gel analysis (Brewer and Fangman 1987). We chose to examine ORI1 (Ferguson et al. 1991) and ORI121 (Walker et al. 1992), which corrrespond to the native chromosomal locations of ARS1 on chromosome IV and ARS121 on chromosome X.

Genomic DNAs were extracted from wild-type (85348C), mcm2-1 (8534-M2), and mcm3-1 (R61-3C) mutant strains that had been grown at $22^{\circ} \mathrm{C}$ and harvested at early log phase. Although mcm 2-1 has a reduced growth rate (Maine et al. 1984) and $m c m 3-1$ is conditional lethal at $38^{\circ} \mathrm{C}$ (Fig. 2b; Gibson et al. 1990), both mutant strains have a doubling time indistinguishable from that of the wild-type strain at $22^{\circ} \mathrm{C}$ (Sinha et al. 1986; Gibson et al. 1990). Genomic DNA was digested either with NcoI, for the detection of replicating ORI1 DNA fragments, or with EcoRI-BamHI, for the detection of replicating ORI121 DNA fragments. Restriction-digested DNA was subjected to two-dimensional agarose gel electrophoresis, which separates different topological forms of replicating DNA. Replicating DNA resulting from initiation events that occurred within the ORI DNA fragments migrates with a characteristic pattern known as the "bubble $^{\prime \prime}$ arc (Fig. 1B, solid arrow). In contrast, replicating DNA resulting from initiation events that occurred outside of the ORI fragment migrates with a characteristic pattern known as the "Y" arc (Fig. 1B, open arrow). The ratio of the intensities of the bubble arc versus the $Y$ arc measures the relative frequency of initiation events emanating from inside and outside the ORI DNA fragment at a particular point in time in a replicating cell population. Because it is difficult to quantitate the intensities 


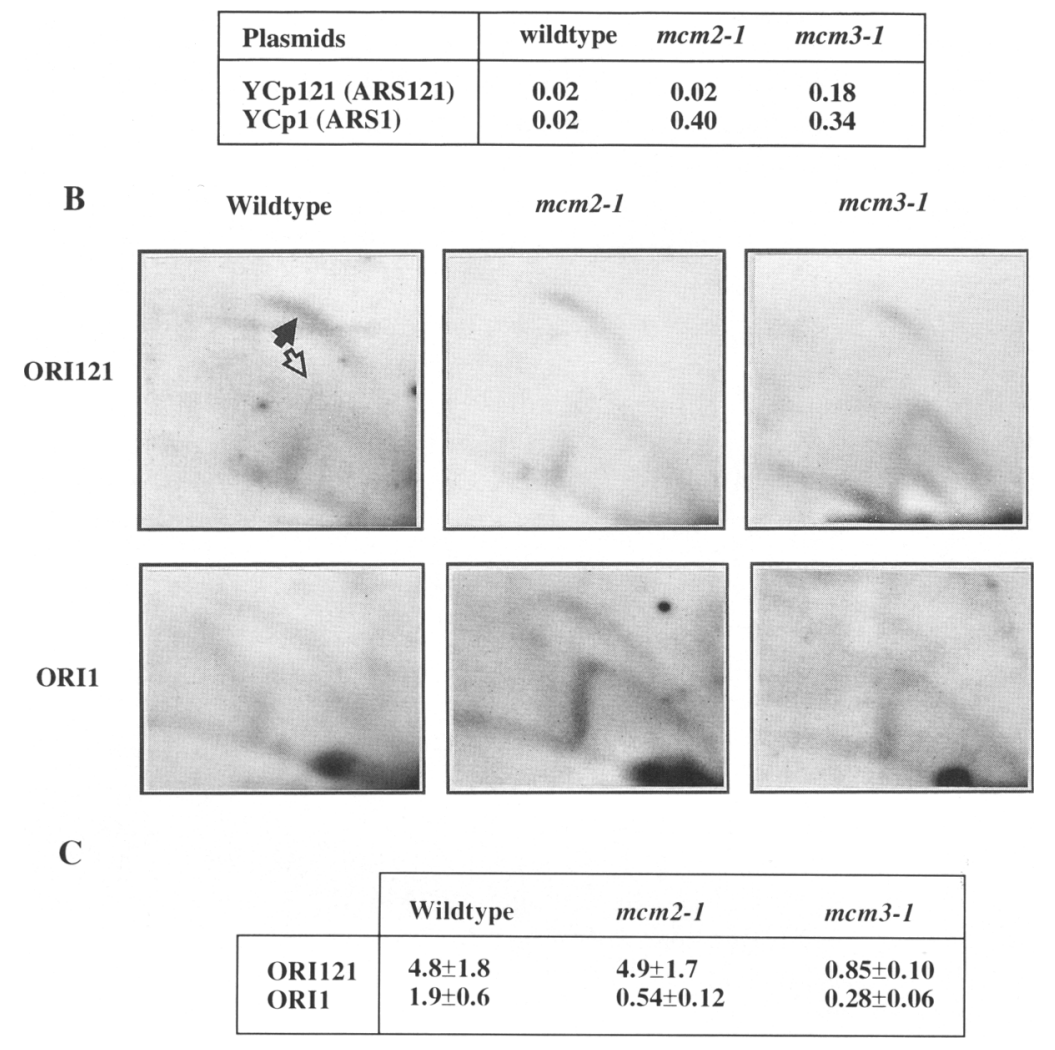

Figure 1. The $m c m$ mutants are defective in the initiation of DNA replication at two chromosomal replication origins. $(A)$ Loss rates per cell division of minichromosomes carrying ARS121 and ARS1 measured over 10 generations of growth at room temperature. $(B)$ Autoradiographs from two-dimensional gel electrophoresis of wild-type $(8534-8 \mathrm{C})$ and mutant (8534-M2 and R61-3C) DNAs. For ARS121, genomic DNA was digested with BamHI and $E c o R I$ and probed with the $3-\mathrm{kb}$ BamHI-EcoRI fragment. For ARS1, DNA was digested with Ncol and probed with the $5-\mathrm{kb} N \mathrm{NoI}-\mathrm{NcoI}$ fragment. Direction of electrophoresis was from left to right for the first dimension and from top to bottom for the second dimension. (Solid arrow) bubble arcs; (open arrow) $\mathrm{Y}$ arcs. $(C)$ Ratio of the intensities of bubble arc vs. $\mathrm{Y}$ arc $(\mathrm{B} / \mathrm{Y})$ for ORI121 and ORIl in wildtype and mutant strains. of the entire bubble or $\mathrm{Y}$ arc, for comparison between strains, only the intensities of the peaks of the bubble arc (B) and $\mathrm{Y} \operatorname{arc}(\mathrm{Y})$ for each replication origin were determined (Fig. 1B, arrows). The ratios (B/Y) for ORI12l and ORI1 in the wild-type strain are 4.8 and 1.9 , respectively (Fig. 1B, left panels; Fig. 1C). Assuming that the frequencies of breakage of parental strands at bubbles (Linskens and Huberman 1989) are comparable between ORIl and ORI121 from the same DNA preparations, these measurements suggest that ORIl2l may be a more active replication origin than ORI1.

Comparing the frequency of initiation events occurring within each of the replication origins in the mutant and wild-type strains, there is a noticeable increase in intensity in the $\mathrm{Y}$ arc relative to the bubble arc for ORI121 in the mcm3-1 $(\mathrm{B} / \mathrm{Y}=0.85)$ but not the $\mathrm{mcm} 2-1$ strain $(B / Y=4.9)$ (Fig. $1 B$, top panels; Fig. $1 C$ ). This result suggests that initiation of DNA synthesis at ORI121 is dependent on the MCM3 gene product. In contrast, initiation events at ORIl are reduced in both the mcm2-1 and mcm3-1 mutant strains with values for $B / Y$ at 0.54 and 0.28 , respectively, suggesting that both MCM2 and MCM3 gene products are required (Fig. 1B, bottom panels|. These results are in agreement with the increased plasmid loss rates observed for ARS121 in mcm3-1 and for ARS1 in both mutants (Fig. 1A). Thus, the ARS-specific loss rates of minichromosomes in the $m \mathrm{~cm}$ mutants reflect the frequency of initiation events
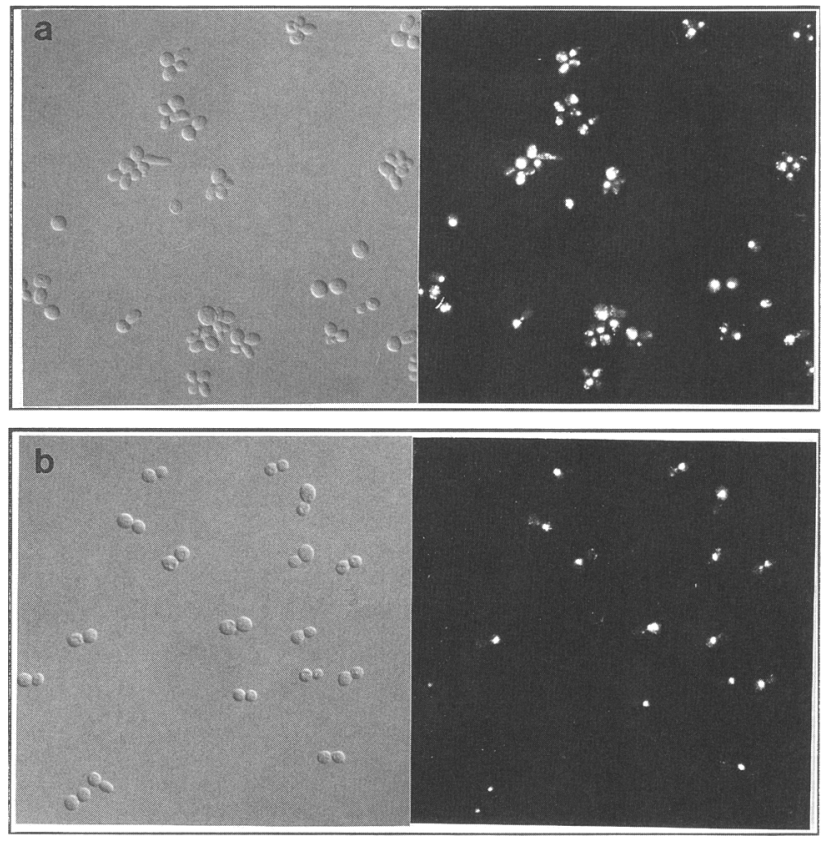

Figure 2. The cell cycle arrest of $m c m 3-1$ is dependent on the RAD9 check point. Cells from mcm3-1 rad9::LEU2 (ED7-1C) $(a)$ and $m c m 3-1(\mathrm{R} 61-4)(b)$ strains were grown at room temperature to early $\log$ phase, shifted to $37^{\circ} \mathrm{C}$ for $6 \mathrm{hr}$, stained with DAPI, and photographed. (Left) Normarsky optics; (right) DAPI. 
occurring at specific ARSs on plasmids and on chromosomes alike.

\section{Defects due to $\mathrm{mcm} 3$ mutation are subject to RAD9 checkpoint control}

Although certain cdc46 mutant alleles arrest with unreplicated DNA (Hennessy et al. 1990), almost all $\mathrm{mcm}$ conditional mutants isolated or constructed in this laboratory exhibit a late $S$ arrest at the nonpermissive condition. A simple explanation for this apparently incongruent phenotype of these presumed replication initiation proteins is that at the nonpermissive condition, because of the ARS-specific defect of these mutants, a small number of replication origins are activated, albeit inefficiently. Elongation from these sites allows replication to proceed until almost two genome equivalents of DNA are produced. This explanation can also be applied to the nuclear division arrest phenotype of the $S$. pombe nda $4^{-}$mutant (M. Yanagida, pers. comm.) and the accumulation of close to two genome equivalents of DNA in the $c d c 21^{-}$mutant (Coxon et al. 1992).

To confirm that the nuclear division arrest phenotype of the $\mathrm{mcm}$ mutants is the result of incomplete replication of DNA rather than a defect in mitosis, we constructed the double mutant, rad9::LEU2 mcm3-1. The mcm3-1 mutation is temperature conditional lethal, giving rise to large budded cells with undivided nuclei at the nonpermissive temperature (Fig. 2b). The rad9 mutation results in defects in the mitosis checkpoint, which feedback-inhibits mitosis until DNA replication is complete (Weinert and Hartwell 1988). At the nonpermissive temperature, the rad $9 \mathrm{mcm} 3-1$ mutant cells are able to enter mitosis (Fig. 2a), suggesting that the nuclear division ar- rest phenotype of the mcm3-1 mutant is the result of feedback inhibition due to defects in DNA replication rather than the result of defects in mitosis.

\section{Preparation of MCM2- and MCM3-specific antibodies}

The extensive sequence similarities shared among MCM2, MCM3, CDC46, and other members of this protein family pose a potential problem of antibody crossreaction. To minimize this possibility, we affinity-purified the MCM2 and MCM3 antisera, using the MCM2 and MCM3 fusion proteins (see Materials and methods). When wild-type yeast extracts were probed with each of these purified antibodies, a single band with a similar molecular mass of $\sim 120 \mathrm{kD}$ was detected consistently in each case (Fig. 3a, lanes 1). Both bands were slightly larger than the predicted molecular masses for MCM2 (101 kD; Yan et al. 1991) and MCM3 (107 kD; Gibson et al. 1990). However, when cells overproducing either MCM2 (Fig. 3a, lanes 2) or MCM3 (Fig. 3a, lanes 3) were analyzed, it was clear that these bands represented the MCM2 and MCM3 proteins, respectively. MCM2-specific antibodies gave a strong signal including several possible degradation products only in the MCM2-overproducing strain (Fig. 3a, left, lane 2). In contrast, a weaker single-band signal corresponding to the MCM2 produced by the endogenous MCM2 gene was observed in strains overproducing MCM3 or $\beta$-galactosidase (Fig. $3 \mathrm{a}$, left, lanes 3,4$)$. Reciprocal results were obtained on an identically prepared filter probed with the MCM3-specific antiserum (Fig. 3a, right). We did not detect any significant antibody cross-reaction between MCM2 and MCM3 (Fig. 3a, cf. lanes 2 and 3 in each panel). In addition, there was no cross-reaction with CDC46, which would run as a $95-\mathrm{kD}$ protein (Hennessy et al. 1990).

\section{b}

a

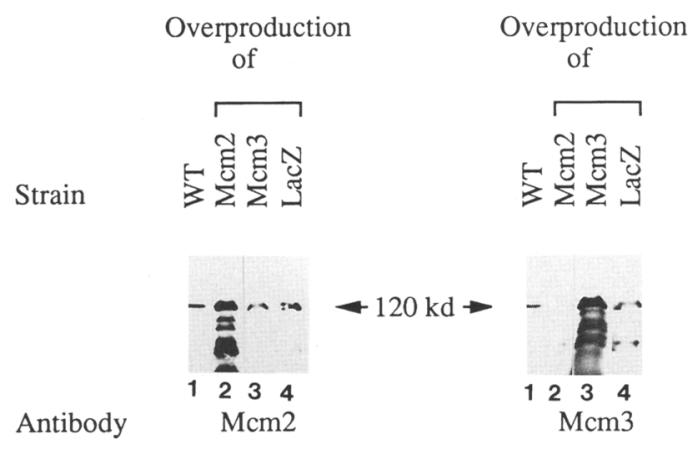

Immunoprecipitation with antibodies to

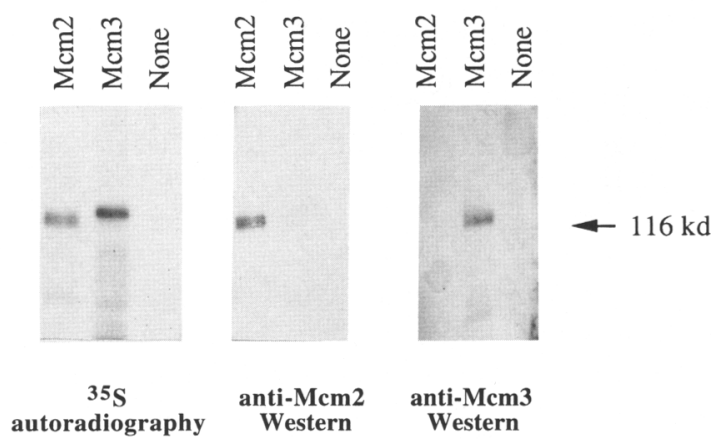

Figure 3. Specificity of MCM2 and MCM3 antibodies. (a) Duplicate sets of samples of protein extracts prepared from the wild-type strain (lanes 1) and strains overproducing MCM2 (lanes 2), MCM3 (lanes 3), and $\beta$-galactosidase (lanes 4) were analyzed by SDS-PAGE and transferred to nitrocellulose membrane. The membrane was then cleaved into two halves. They were probed with antibodies to MCM2 (1:500 dilution, left) or MCM3 (1:2000 dilution, right). Equivalent amounts of proteins were added in each lane. $(b)$ Immunoprecipitation of ${ }^{35} \mathrm{~S}$-labeled MCM2 and MCM3 followed by SDS-PAGE and then transferred to nitrocellulose membrane. The resulting membrane containing duplicate sets of samples was first allowed to undergo ${ }^{35} \mathrm{~S}$ autoradiography: Only one of the duplicates is shown (left). The identical Western blots were then probed with either MCM2-specific (center) or MCM3-specific antiserum (right). 
We also examined the possibility that these antibodies might cross-react with the native MCM2 and MCM3 proteins by immunoprecipitating extracts of ${ }^{35} \mathrm{~S}$-labeled yeast cells with each of these two antibodies. Precipitates were solubilized and proteins separated on SDSPAGE and then transferred to nitrocellulose membrane in duplicate sets. Autoradiography indicates that each antiserum only reacted with one predominant protein species of similar but distinct molecular mass of $\sim 120$ $\mathrm{kD}$ (Fig. 3b, left; only one of the duplicates shown). These same Western blots probed with either MCM2specific antiserum (Fig. 3b; center) or MCM3-specific antiserum (Fig. 3b, right) showed reaction only with the corresponding protein/antiserum precipitate but no cross-reaction between these antibodies. Again, no trace of CDC46 was detected.

Subsequent experiments to analyze the intracellular distribution of MCM2 and MCM3 were carried out using these highly specific antibodies.

\section{Distribution of MCM2 and MCM3 in wild-type cells}

We first analyzed the localization of MCM2 and MCM3 in exponentially growing wild-type yeast cells by indirect in situ immunofluorescence (Kilmartin and Adams 1984) using purified antibodies against either MCM2 or MCM3 and a FITC-labeled anti-rabbit secondary antibody. Cells were fixed by adding formaldehyde directly to the medium to minimize artifacts. As shown in Figure 4 , both antibodies gave rise to heterogeneous staining similar to that observed for CDC46 (Hennessy et al. 1990). Some cells displayed strong nuclear staining, whereas others displayed only diffuse cytoplasmic staining. The second antibody alone did not display any staining (data not shown), suggesting that the staining was specific.

This heterogeneity in staining is apparently cell cycle dependent. For both antibodies, unbudded cells invariably gave clear nuclear staining, whereas premitotic budded cells (single nucleus) showed only weak cytoplasmic staining. In contrast, postmitotic large budded cells (two divided nuclei) showed either nuclear or cytoplasmic staining. To further define the cell cycle positions of these postmitotic large budded cells, we double-stained them with a rat anti-tubulin monoclonal antibody and a rhodamine-conjugated anti-rat secondary antibody. Cells can be grouped into five categories on the basis of cell and spindle morphology: (I) unbudded; (II) small bud with one nucleus; (III) large bud with undivided nucleus and thick mitotic spindles; (IV) large bud with well separated nuclei and long mitotic spindles; and (V) large bud with well separated nuclei and disassembled mitotic spindles (Fig. 5, top panels). As summarized in the table in Figure 5 and also shown in Figure 4, cells in categories $\mathrm{I}$ and $\mathrm{V}$ always display nuclear staining, whereas cells in category III always show cytoplasmic staining. However, cells in category IV display two staining patterns: $47 \%$ (MCM2) or 55\% (MCM3) of the cells show nuclear staining, whereas the rest of the cells show only cytoplasmic staining. In contrast, cells in category II display heterogeneous staining patterns: $61 \%$ (MCM2) or $80 \%$ (MCM3) of cells show predominantly cytoplasmic staining while the rest of the cells show nuclear or partial nuclear staining (Fig. 5, top panels). Therefore, it can be
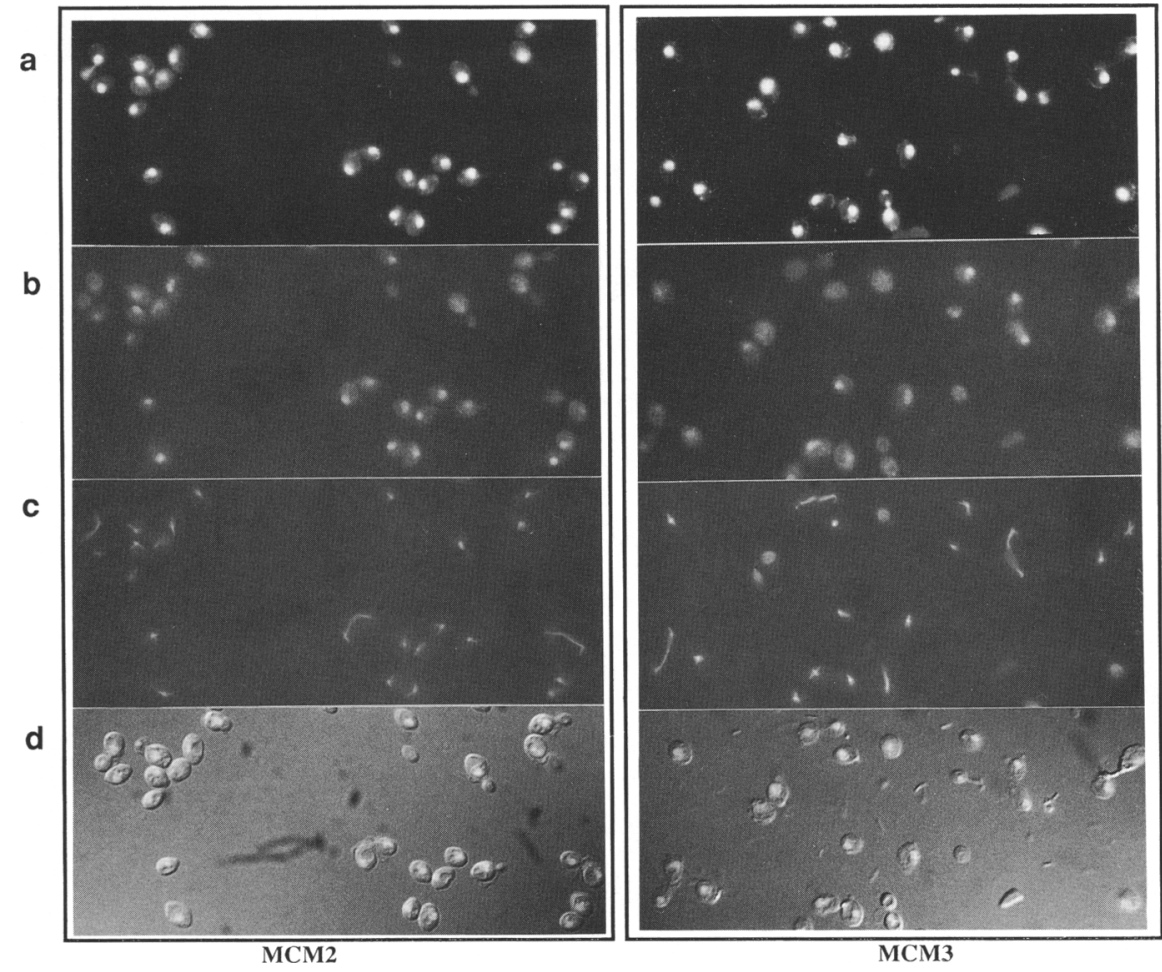

Figure 4. Immunostaining of MCM2 and MCM3 in wild-type diploid cells (8534/ R61). Asynchronous cells were stained with DAPI $(a)$, affinity-purified rabbit antiMCM2 (left) or MCM3 (right) antibody (1:5) /FITC-conjugated goat anti-rabbit antibody $(1: 80),(b)$ mouse anti- $\alpha$-tubulin antibody YOL1/34/rhodamine-conjugated rat anti-mouse antibody $(c)$, and same cells viewed by Normarsky light microscopy (d). 
Figure 5. Nuclear staining of MCM2 or MCM3 in diploid cells at each cell cycle stage (see legend to fig. 4). (Top) Micrographs of cells representing each cell cycle stage. From top to bottom: No staining (Normarsky), anti- $\alpha$-tubulin, DAPI, antiMCM2. (Bottom) Percentage of cells with nuclear staining of MCM2 or MCM3 at each cell cycle stage. On the basis of cell and mitotic spindle morphology, 355 cells (MCM2 staining) and 177 cells (MCM3 staining/ examined by indirect immunofluorescence microscopy were grouped and then scored as either nuclear staining positive or negative. (I) Unbudded; (II) small bud with one nucleus; (III) large bud with undivided nucleus and thick mitotic spindles; (IV) large bud with well-separated nuclei and long mitotic spindles; and (V) large bud with well separated nuclei and disassembled mitotic spindles. $1+1$ Nuclear staining; (-) non-nuclear staining (small stippled circle) nucleus; (large circle) cell; (line) mitotic spindle; $(\%)$ percent of cells scored in each cell cycle stage. Actual number of cells scored in each group are shown in parentheses. MCM2 staining: I (175); II (70); III (34); IV (57); V (19). MCM3 staining: I(106); II (36); III (8); IV (20); V (8). concluded that MCM2 and MCM3 enter the nucleus some time at the end of anaphase and persist there throughout the $G_{1}$ phase until the beginning of the next cell cycle.

\section{The distribution of MCM2 and MCM3 in cells arrested at different cell-cycle stages}

The above observation suggests that the nuclear localization of MCM2 and MCM3 is dependent on some specific cell cycle events. To define these events, we have analyzed the distribution of MCM2 and MCM3 in cells arrested at specific cell cycle stages by cell division cycle $\mid c d c)$ gene mutations or specific inhibitors (Pringle and Hartwell 1981). The results are summarized in Table 1. Like CDC46, MCM2 and MCM3 are predominantly in the nucleus in $\mathrm{G}_{1}$ phase cells only (Fig. 6). In addition, we observed partial nuclear staining in $62 \%$ of the MCM2 antisera-treated, or $24 \%$ of the MCM3 antisera-treated, $\mathrm{HU}$-arrested cells (Fig. 7). In these cells, staining in the nucleus is generally weak and often occupies a smaller region of the nucleus than that stained by DAPI. The absence of nuclear staining in cells arrested at other stages of the cell cycle is not the result of the absence of the MCM2 and MCM3 proteins in the cells. Western blots of extracts from these arrested cells indicate that both proteins are present (data not shown). Thus, MCM2 and MCM3 enter the nucleus after the execution point of CDC15, which defines a very late stage of mitosis with nuclear division completed and mitotic spindles fully extended. After $G_{1}$ phase, they disappear from the nucleus at approximately the same time: after the execution points of CDC4 (or CDC34) and CDC7 but before the HU block at a very early stage of DNA replication.

\section{Localization of MCM2 and MCM3 by nuclear fractionation}

Immunostaining represents only one way of localizing a protein. Sometimes an antigen may be masked by some

Table 1. Localization of MCM2 and MCM3 at different stages of the cell cycle by indirect immunofluorescence

\begin{tabular}{|c|c|c|c|c|c|c|c|c|c|c|}
\hline $\begin{array}{l}\text { Arrest } \\
\text { point }\end{array}$ & Start & & $\mathrm{G}_{1} / \mathrm{S}$ & & & $\mathrm{G}_{2} / \mathrm{M}$ & & & $\Gamma$ & \\
\hline $\begin{array}{l}\text { Cell cycle } \\
\text { mutation or }\end{array}$ & $c d c 28$ & $\alpha$-factor & $c d c 4$ & $c d c 34$ & $c d c 7$ & $\mathrm{HU}$ & $c d c 2$ & $c d c 17$ & $\operatorname{cdc14}$ & $c d c 15$ \\
\hline inhibitor & & & & & & & & & & \\
\hline Mcm2 & + & + & + & + & + & \pm & - & - & - & - \\
\hline $\mathrm{Mcm} 3$ & + & + & + & + & + & \pm & - & - & - & - \\
\hline
\end{tabular}

Cells were arrested by either shifting to $37^{\circ} \mathrm{C}$ or incubated with inhibitors for $\sim 3.5 \mathrm{hr}$. Mitotic spindles were stained to serve both as a positive control for the staining and as indicators of cell cycle stages. Only cells with mitotic spindle stainings were scored. $(+)$ Nuclear staining; (- | non-nuclear staining. For the $c d c$ strains used, refer to Table 2. 


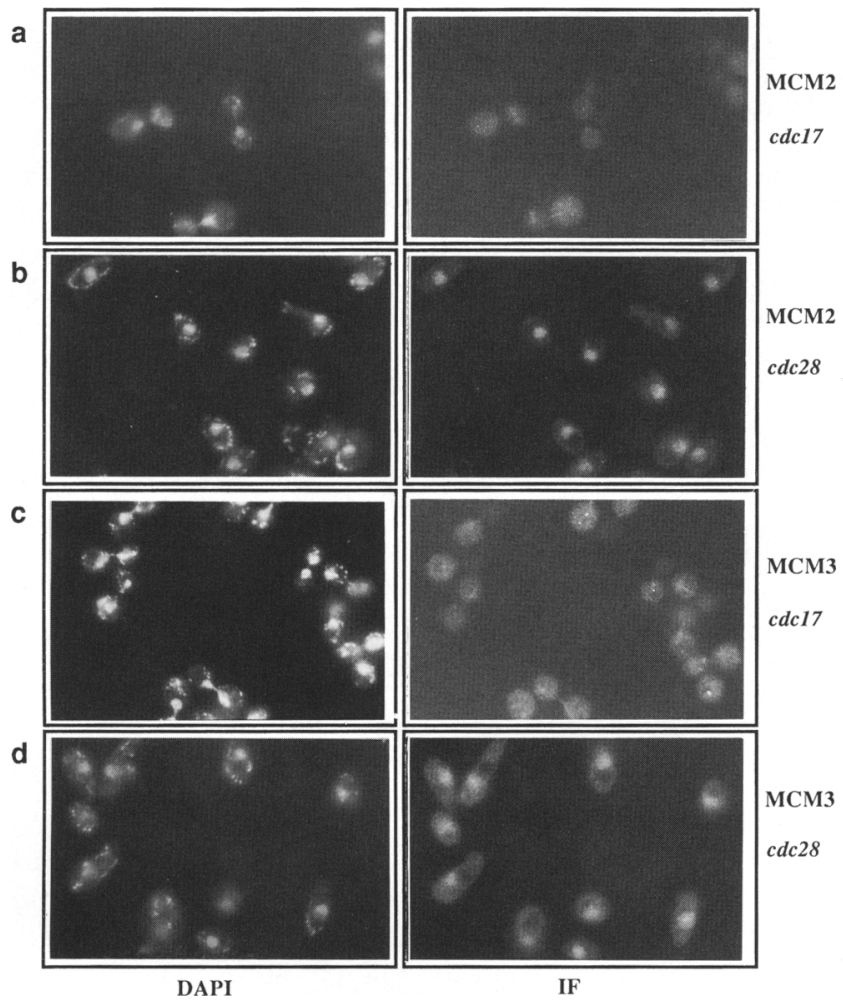

Figure 6. Immunostaining of MCM2 and MCM3 in cell cyclearrested cells. Arrested cells of $c d c 28-1(b, d)$ and $c d c 17-1(a, c)$ stained with DAPI (left) or anti-MCM2 $(a, b$, right) or MCM3 antibodies $(c, d$, right $)$ as described in Fig. 4.

\section{Subnuclear localization of MCM2 and MCM3}

Having determined that MCM2 and MCM3 are in the nucleus during $G_{1}$ stage of the cell cycle, we further examined their subnuclear distribution in an asynchronous population of cells. Wild-type yeast nuclei were isolated and extracted with a buffer containing different concentrations of $\mathrm{NaCl}$. The nuclear material was pelleted by centrifugation; the extracted proteins were in the supernatant. We used histone H2B as a control for the extraction. As expected, histone $\mathrm{H} 2 \mathrm{~B}$ was completely associated with the pellet fraction at low salt concentrations, was partially extracted by $0.8 \mathrm{M}$ salt, and became completely soluble at $2 \mathrm{M}$ salt (Burton et al. 1978). Surprisingly, MCM2 and MCM3 were present in both supernatant and pellet fractions regardless of the salt concentration used (Fig. 9a). This result was not unique to the extraction buffer used, similar results were obtained with other extraction buffers (data not shown). We noticed that the ratio between the supernatant form and the pellet form varies slightly but not significantly at different salt concentrations, suggesting that the two forms are distinct. The soluble form is not likely to be a contaminant from the cytoplasm on the basis of two lines of evidence: (1) the internal control, the $32-\mathrm{kD}$ MCM3 degradation product (Fig. 8), indicated little, if any, cytoplasmic contamination in our nuclear preparation; and (2) in cdc15 (Fig. 8, right panels), as well as arrested cells in a number of other cell cycle stages (data not shown), very little MCM2 and MCM3 were found in the nuclear fraction.

We then examined the nature of the subnuclear structure with which MCM2 and MCM3 are associated. Some

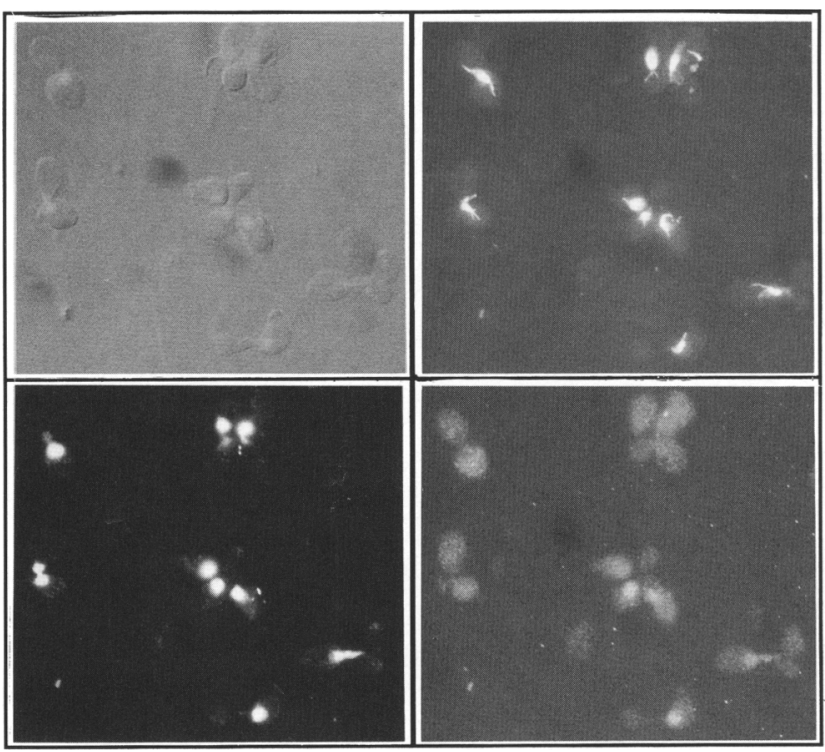

Figure 7. Immunostaining of MCM3 in HU-arrested cells. Logphase diploid cells (8534/R61) were treated with $\mathrm{HU}$ for $3 \mathrm{hr}$ at room temperature and then (clockwise) not stained or stained with anti-tubulin antiserum; and anti-MCM3 antiserum; and DAPI. 

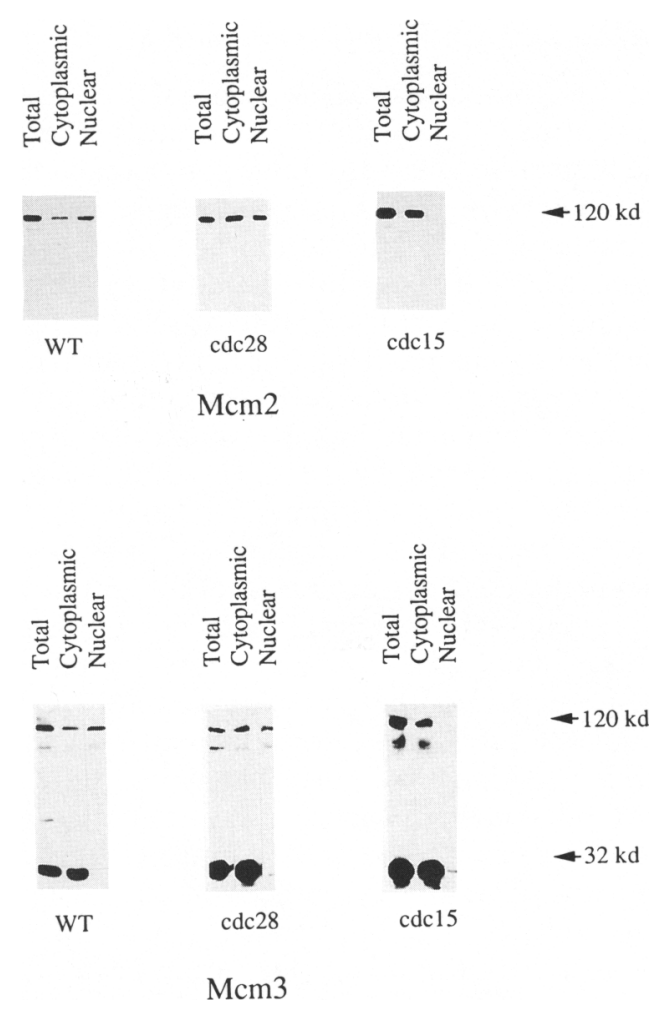

Figure 8. Subcellular fractionations of MCM2 and MCM3. Wild-type (BJ2168) and arrested cdc28-1 (K28 5-1) and cdc15 (DK25-7D) cells were fractionated into cytoplasmic and nuclear fractions. The two fractions, as well as the lysate before fractionation, were adjusted to equivalent volumes and analyzed by Western blot with antibodies to either MCM2 or MCM3.

of the possibilities include nuclear envelope, nuclear matrix, chromatin, nucleoli, or even contaminants of cytoskeletal structures. To differentiate these possibilities, we further treated the CE buffer-extracted nuclear pellet with different reagents: DNase I, RNase A, and the nonionic detergent NP-40. The only treatment that efficiently removed MCM2 and MCM3 from the nuclear pellet was digestion by DNase I (Fig. 9b). These experiments suggest that there are two subnuclear populations of MCM2 and MCM3, one that is free in the nucleoplasm and one that may be chromatin-bound.

\section{Discussion}

\section{A family of proteins involved in the initiation} of DNA synthesis at replication origins

MCM2 and MCM3 are two proteins required for the efficient propagation of autonomously replicating plasmids in $S$. cerevisiae. They are members of a recently identified protein family, MCM2-3-5, believed to be involved in the initiation of DNA replication (Hennessy et al. 1991; Yan et al. 1991; Chen et al. 1992). Defects in these proteins lead to instability of plasmids that carry specific ARSs. The ARS-specific minichromosome maintenance defect suggests that the lesion is in the ini- tiation of DNA synthesis at ARSs that drive the replication of individual plasmids. In this paper we show that MCM2 and MCM3 play a crucial role in the initiation of DNA synthesis at chromosomal replication origins. Defects in these proteins result in reduced usage of specific chromosomal replication origins that are also sensitive to the $\mathrm{mcm}$ mutations when isolated on plasmids. Although we do not know the precise role of the MCM proteins in the initiation of DNA synthesis at replication origins, the association of both MCM 2 and MCM3 with chromatin suggests that these proteins may be directly involved in the initiation mechanism. Both MCM2 and MCM3 are periodic nuclear proteins whose localization in the nucleus is temporally and spatially programmed with respect to stages of the cell cycle. Their association with chromatin presumably leads to the initiation of DNA synthesis, and their subsequent disappearance from the nucleus would then prevent reinitiation of DNA synthesis at replication origins.

\section{Time of arrival and departure in the nucleus}

Both immunostaining and cell fractionation studies indicate that MCM2 and MCM3 enter the nucleus at the end of mitosis, persist there throughout $G_{1}$ phase, pass Start, and disappear from the nucleus sometime after the $\mathrm{G}_{1} / \mathrm{S}$ transition point. The time of nuclear entry of the MCM proteins coincides with that reported for CDC46/ MCM5 (Hennessy et al. 1990), suggesting that the mechanism (or mechanisms) for the temporal nuclear import of the MCM2-3-5 protein family may be the same or coregulated.

Because MCM2 and MCM3 appear to play a key role in the chain of events that lead to the initiation of DNA synthesis at replication origins, it is important to pinpoint their time of disappearance from the nucleus. In our studies, MCM2 and MCM3 are still in the nucleus in $c d c 7$-arrested cells but are predominantly cytoplasmic in $\mathrm{HU}$-arrested cells. The execution point for $\mathrm{CDC} 7$ has been placed after those of CDC4 and CDC34 (Hereford and Hartwell 1974) but before replication initiation because $c d c 7$ mutants arrest before the HU-sensitive step, exhibiting no detectable new DNA synthesis (Hartwell 1976). HU is an inhibitor of ribonucelotide reductase and, therefore, the biosynthesis of deoxynucleotides. When an asynchronous culture is treated with HU, cells that are already in $S$ phase will experience an almost immediate arrest, but most cells will arrest at slightly different positions of the beginning of $S$ as nucleotide pools are depleted. The heterogeneous nuclear staining of MCM2 and MCM3 in HU-treated cells is consistent with this expectation. A previous report indicated that CDC46 is absent in the nuclei of HU-arrested cells (Hennessy et al. 1990) while we observed partial nuclear staining of MCM2 and MCM3 in some HU-arrested cells. It is not clear whether these minor differences represent differences in the criteria for scoring or actual differences in the time of disappearance of these proteins. Our studies place the disappearance of MCM2 and MCM3 from the nucleus sometime after Start, at or soon 
b

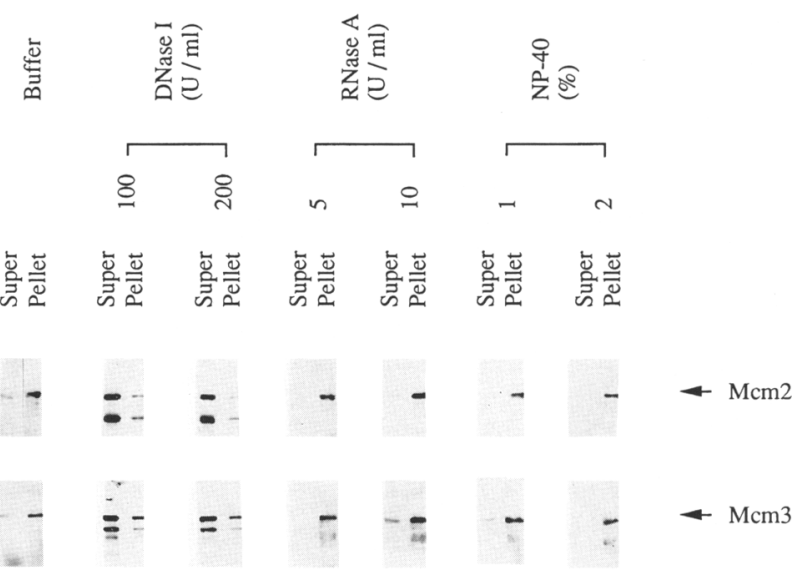

Figure 9. Subnuclear fractionations of MCM2 and MCM3. (a) Nuclei derived from wild-type cells were extracted with different concentrations of $\mathrm{NaCl}$ in buffer $\mathrm{CE}$. After centrifugation, the supernatant and pellet were adjusted to equal volume and analyzed by Western blot with antibodies to MCM2 and MCM3. (b) Nuclei extracted by the CE buffer were resuspended in buffer SE supplemented with different extraction reagents. After 10 min treatment at $37^{\circ} \mathrm{C}$, nuclei were centrifuged, and the resulting supernatant and pellet were analyzed by Western blot.

after the time of replication initiation. Replication initiation might signal the removal of MCM2 and MCM3 from the nucleus.

\section{Association with chromatin}

Inside the nucleus, MCM2 and MCM3 are found not only in a soluble form (presumably in the nucleoplasm) but also in a form tightly associated with DNA. We do not know whether both of these forms are present in the same nucleus or whether each is derived from nuclei at different positions within the $G_{1}$ phase. It is interesting to note that hP1, the human homolog of MCM3, is found in both cytoplasmic and nuclear fractions. Extraction of hP1 from the nuclear fraction also requires a high concentration salt wash, suggesting that it is bound to some nuclear structure (Thommes et al. 1992). This tight binding of MCM2 and MCM3 to DNA presumably is the precursor for subsequent events that lead to the initiation of DNA synthesis at replication origins. Because the MCM proteins are already present in the nucleus during late $M$ phase, we surmise that additional modifications, perhaps involving S-phase replication factor (RF-S) (D'Urso et al. 1990), may be the activation signal for these MCM proteins.

\section{Regulation of DNA synthesis by nuclear membrane assembly and disassembly}

The licensing factor model was originally proposed to explain the requirement for nuclear membrane perturbation to get a new round of DNA synthesis in Xenopus egg extracts (Blow and Laskey 1988). The MCM2-3-5 protein family of $S$. cerevisiae has many of the properties prescribed for the licensing factor. The timing of the nuclear entry of this family of replication proteins is intriguing because yeast is not known to have an open mitosis and there is no obvious advantage for these replication proteins to be in the nucleus anytime before $G_{1}$ phase. Furthermore, it is clear that yeast has the capacity to deliver specific proteins, such as SWI5 (Moll et al. 1991) to the nucleus at other points of the cell cycle for the temporal function of those proteins. If the MCM2-3-5 protein family plays the role of replication factors that triggers the initiation of DNA synthesis at Start, then it would suggest that the mechanism for the time- and space-coordinated, transient activation of replication initiation proteins may have coevolved with nuclear membrane biogenesis in eukaryotes. The finding of homologs of this protein family in other eukaryotes, from $S$. pombe (Coxon et al. 1992) to human (Thommes et al. 1992), lends support to the idea that this regulatory mechanism may be universal and highly conserved.

\section{Materials and methods}

Strains and plasmids

Escherichia coli strains used are as follows: DH5 $\alpha$ (GIBCO BRL) was used for routine plasmid construction and preparation; JM83 (F-ara $\Delta($ lac-proAB) rpsL (Str') $\phi 80 d \Delta($ lacZ)M15]) was used to produce $\mathrm{LacZ} / \mathrm{MCM} 2$ fusion and $\mathrm{LacZ}$ proteins; RR1 (hsdS20) was used for producing TrpE and TrpE/MCM3 fusion proteins. The $S$. cerevisiae strains used are listed in Table 2. Isogenic wild-type and mutant $m c m 2-1$ strains were constructed by gene transplacement (Boeke et al. 1984) using YIp56/mcm2-1, an integrating plasmid containing the mcm2-1 allele. Plasmids used for overproducing MCM2, $\mathrm{MCM} 3$, and $\beta$-galactosidase in the $\mathrm{F} 808$ yeast strain are pB620.MCM2 (URA3 GAL1::MCM2 $2 \mu$ ARS); pB620.MCM3 (URA3 GAL1::MCM3 $2 \mu$ ARS); and pB620.lacZ (URA3 GAL1::IacZ $2 \mu$ ARS).

\section{Plasmid loss rates}

Mitotic plasmid stability assays were carried out as described (Gibson et al. 1990). Plasmid loss rate is determined by 
Table 2. Yeast strains used in this study

\begin{tabular}{|c|c|c|}
\hline Strain & Description/genotype & Source \\
\hline $6433-4 \mathrm{C}$ & MATa $c d c 4-1$ leu2-3 & \\
\hline $7522-7 \mathrm{C}$ & MATa cdc7-1 his4-912 & \\
\hline $8534-8 \mathrm{C}$ & MAT $\alpha$ leu2-3,112 ura3-52 his4- $\Delta 34$ & G. Fink (MIT, Cambridge, MA) \\
\hline $8534-\mathrm{M} 2$ & MATa leu2-3,112 ura3-52 his4- $\Delta 34 \mathrm{mcm} 2-1$ & this study \\
\hline $8534 /$ R61 & MATa/MATa ura3-52/ura3-52 leu2/leu2 +/his3-11his $4-\Delta 34 /+$ +/lys2 +/ade2 +/trp1 & this laboratory \\
\hline BJ2168 & MATa pep4-3 prc1-407 prb-1122 ura3-52 trp1 leu2 & $\begin{array}{l}\text { D. Shore (Columbia University, } \\
\text { NY) }\end{array}$ \\
\hline DK25-7D & MATa cdc15 ade1 ura1 & D. Kabak (NIMDS, NJ) \\
\hline E3-16 & MATa cdc34-1 ade1 ade2 gal his7 lys2 tyr1 ura1 & S. Gibson, this laboratory \\
\hline ED7-lc & MATa ura3-52 leu2-3,112 mcm3-1 rad9::LEU2 & this study \\
\hline F472 & MATa $c d c 2-1$ & \\
\hline F808 & MATa leu2-3,112 ura3-52 his4.519 ade1-100GAL1 & G. Fink \\
\hline $\mathrm{H} 17 \mathrm{ClAl}$ & MATa his7 ura1 cdc17-1 & $\begin{array}{l}\text { L. Hartwell (University of } \\
\text { Washington, Seattle) }\end{array}$ \\
\hline JSY542 & MATa ura $c d c 8^{t s} \operatorname{trp} 1 M A L G A L[T R P 1 \mathrm{R}$ l circle] & $\begin{array}{l}\text { V. Zakian (Fred Hutchinson } \\
\text { Cancer Center, Seattle, WA) }\end{array}$ \\
\hline $\mathrm{K} 1328-2$ & MATa ura3 leu ade cdc13 & V. Zakian \\
\hline K28 5-1 & MATa ura3 cdc28-1 & V. Zakian \\
\hline R61-4 & MAT $\alpha$ mcm3-1 ura3-52 leu2-3,112 his $4 \Delta 34$ & this laboratory \\
\hline $\mathrm{R} 61-3 \mathrm{C}$ & MAT $\alpha$ mcm3-1 ura3-52 leu2-3,112 his $4-\Delta 34$ & S. Gibson \\
\hline TD4 & MAT $\alpha$ leu2-3,112 ura3-52 his4-519 trp1-289 & $\begin{array}{l}\text { T. Donahue (University of } \\
\text { Indiana (Bloomington) }\end{array}$ \\
\hline XMB4 12b & MATa sst1-1 (ura-) & P. Smith, this laboratory \\
\hline
\end{tabular}

$1-\{F / I\}^{1 / N}$, where $I$ is the initial percentage of plasmid-containing cells and $F$ is the percentage of plasmid-containing cells after $N$ generations.

\section{Two-dimensional gel electrophoresis}

Procedures for two-dimensional gel electrophoresis analysis of replicating DNA have been described in Brewer and Fangman (1987). For a given strain, DNA from the same DNA preparation was used for the study of both ORIl and ORI121. Typically, between 30 and $50 \mu \mathrm{g}$ of DNA is loaded in each gel. Probes for detecting ORI1 and ORI121 were prepared as follows. Plasmid DNA containing ARS1 or ARS121 was digested with NcoI or BamHI-EcoRI, respectively. Restriction fragments were gel purified and ${ }^{32} \mathrm{P}$-labeled by random oligonucleotide priming (Feinberg and Vogelstein 1983). Intensities of the peaks of the B and $\mathrm{Y}$ arcs were determined by using the Bio-Rad video densitometer (model 620). Each number $(\mathrm{B} / \mathrm{Y})$ is the average of three to four experiments except for that of ORIl in the mcm3-1 strain, in which case, $\mathrm{B} / \mathrm{Y}$ is the average of two experiments.

\section{Production of MCM2 and MCM3 fusion proteins}

E. coli strains RRl carrying the trpE vector $\mathrm{pAH} 3 \mathrm{~b}$ or the $\operatorname{trp} E /$ MCM3 fusion plasmid p3MCM3HH were induced with $20 \mu \mathrm{g} /$ $\mathrm{ml}$ of indoleacrylic acid at $30^{\circ} \mathrm{C}$ for $4 \mathrm{hr}$ (Dieckmann and Tzagoloff 1985). Mid-log-phase E. coli strain JM83 cells containing either the LacZ/MCM2 fusion plasmid pSM2HB or the LacZ vector $\mathrm{pSM} 2 \Delta \mathrm{X}$ were induced with $1 \mathrm{mM}$ isopropyl- $\beta$-D-thiogalactopyranoside at $37^{\circ} \mathrm{C}$ for $6 \mathrm{hr}$ (Ruther and Muller-Hill 1983).

\section{Preparation of anti-MCM2 serum}

The LacZ/MCM2 fusion protein was purified by running the crude extract (which contains $\sim 40 \%$ fusion protein) on a $6 \%$ SDS-polyacrylamide gel, cutting out the $\mathrm{LacZ} / \mathrm{Mcm} 2$ protein band (visualized by staining with $0.25 \mathrm{M}$ ice-cold $\mathrm{KCl}$ ), and elec- troeluting the protein from the gel (Hunkapiller et al. 1983). Two giant flemish/chinchilla rabbits were initially injected with $0.2 \mathrm{mg}$ of the purified protein and $0.7 \mathrm{ml}$ of Freund's complete adjuvant (Vaitukaitis 1981), boosted twice with $0.1 \mathrm{mg}$ of protein and Freund's incomplete adjuvant 27 and 35 days later, respectively. Blood was removed from the rabbits 10 days after the second boost. The blood was left at room temperature for 1 $\mathrm{hr}$ and then at $5^{\circ} \mathrm{C}$ overnight. The serum was spun at $2000 \mathrm{rpm}$ for $15 \mathrm{~min}$, transferred to fresh tubes, and stored at $-20^{\circ} \mathrm{C}$.

\section{Affinity columns and antibody purification}

Fusion proteins, in either crude extracts or partially purified fractions, were boiled in $2 \mathrm{ml}$ of buffer [ $50 \mathrm{~mm}$ HEPES ( $\mathrm{pH} 7.5$ ), $1 \%$ SDS, $0.1 \% \beta$-mercaptoethanol] per 100 -ml culture for $2 \mathrm{~min}$. After being spun at $30 \mathrm{~K}$ for $30 \mathrm{~min}$, the supernatants were dialyzed against 1 liter of $20 \mathrm{~mm}$ HEPES (pH 7.5), $0.1 \% \beta$-mercaptoethanol. They were then coupled with $3 \mathrm{ml}$ of Affi-gel 15 (Bio-Rad Laboratories, Richmond, CA) per $100 \mathrm{ml}$ culture at room temperature for at least $1 \mathrm{hr}$. Columns containing the following fusion proteins were prepared in this way: pSM2HB (partially purified), pSM2 $\mathrm{X}$ (crude extract), p3MCM3HH (partially purified), and pAH3 (crude extract). The MCM2 antiserum was purified (at $4^{\circ} \mathrm{C}$ ) on the pSM $2 \Delta \mathrm{X}$ and pSM2HB columns as follows: $25 \mathrm{ml}$ of serum was diluted fivefold with Western buffer and passed twice through the pSM $2 \Delta \mathrm{X}$ column at a slow flow rate. The flowthrough was reapplied to the pSM2HB column, which was then washed extensively with $100 \mathrm{ml}$ of Western buffer [ $50 \mathrm{mM}$ Tris- $\mathrm{HCl}$ ( $\mathrm{pH} 8.3) 150 \mathrm{~mm} \mathrm{NaCl}$. The retained antibodies were eluted with $15 \mathrm{ml}$ of $0.05 \mathrm{~mm}$ glycine $(\mathrm{pH} \mathrm{2.2)}$ into $1 \mathrm{ml}$ of $10 \times$ Western buffer. The MCM3 antiserum /Gibson 1989) was purified in a similar way, with pAH3 and p3MCM $3 \mathrm{HH}$ as the first and second columns, respectively.

\section{Yeast protein preparations for Western blot analysis}

Yeast cells $\left(10^{9}\right.$ cells $\left./ \mathrm{ml}\right)$ were lysed by vortexing with glass 
beads. After a low-speed spin at $1000 \mathrm{rpm}$ for $2 \mathrm{~min}$, the supernatants were mixed with equal volume of $2 \times$ SDS-PAGE loading buffer and boiled for $10 \mathrm{~min}$. Cell walls and other debris were then removed by spinning the cells for $15 \mathrm{~min}$ in a microcentrifuge. Ten microliters of protein samples was separated on SDS-PAGE and transferred onto nitrocellulose membranes 10.1 $\mu \mathrm{m}_{;}$Schleicher \& Schuell, Keene, NH) using the semidry transfer unit (Hoefer Scientific Instruments, San Francisco, CA). The membranes were then treated at room temperature with $5 \%$ nonfat dry milk (A\&P) dissolved in Western buffer $150 \mathrm{mM}$ Tris (pH 8.3), $150 \mathrm{~mm} \mathrm{NaCl}$ ) for at least $1 \mathrm{hr}$ to block nonspecific protein-binding sites. They were then incubated with the first antibody at room temperature for $1 \mathrm{hr}$. After $3 \times$ washing $15 \mathrm{~min}$ each), they were incubated with goat anti-rabbit IgG horseradish peroxidase conjugate (1:7500 dilution) for $1 \mathrm{hr}$. After another $3 \times$ washing ( $\mathrm{NaCl}$ was added to $1 \mathrm{M}$ in the last wash), the membranes were developed with ECL reagents (Amersham, $\mathrm{UK})$.

\section{${ }^{35}$ S-labeling and immunoprecipitation}

Yeast strain BJ2168 was grown in YEPD to $\sim 1 \times 10^{7}$ cells $/ \mathrm{ml}$ at $30^{\circ} \mathrm{C}$. After being washed with $\mathrm{ddH}_{2} \mathrm{O}$, cells $\left(1 \times 10^{9}\right)$ were grown in $\mathrm{SD}$ supplemented with uracil, leucine, tryptophan, and $2 \mathrm{mCi}$ of Trans ${ }^{35} \mathrm{~S}$-label (ICN, Costa Mesa, CA) for $3 \mathrm{hr}$ at $30^{\circ} \mathrm{C}$. Labeled cells were washed once, resuspended in $1 \mathrm{ml}$ of NP-40 lysis buffer [50 mM Tris (pH 8), $150 \mathrm{~mm} \mathrm{NaCl}, 1 \% \mathrm{NP}$ 40], and broken with acid-washed glass beads. After a 15-min spin in a microcentrifuge, the supernatant was removed carefully to exclude as much lipid layer as possible. Immunoprecipitation was performed essentially according to Harlow and Lane (1988). The supernatant was precleared with fixed Staphylococcus aureus cells (Calbiochem, La Jolla, CA) coated with rabbit serum. The MCM2 and MCM3 antibody-antigen complexes were brought down with protein A-agarose (Calbiochem, La Jolla, CA).

\section{Indirect immunofluorescence}

The procedure (performed at room temperature unless indicated otherwise) was adapted from that of Kilmartin and Adams (1984) and is described only briefly here. Yeast cells were directly fixed in growth media with $3.7 \%$ formaldehyde for $1 \mathrm{hr}$. The cell walls were removed by incubating in $0.5 \mathrm{ml}$ of the same buffer plus $1 \mu \mathrm{l}$ of $\beta$-mercaptoethanol and $20-50 \mu \mathrm{l}$ of Zymolyase $100 \mathrm{~T}$ (ICN Biomedicals) for $30 \mathrm{~min}$ at $37^{\circ} \mathrm{C}$. The cells were transferred to polylysine-coated multiwell slides and treated with $-20^{\circ} \mathrm{C}$ methanol for $6 \mathrm{~min}$ and $-20^{\circ} \mathrm{C}$ acetone for $40 \mathrm{sec}$. After blocking with $5 \%$ fat-free dry milk $(A \& P)$ in the Western buffer for $\sim 20 \mathrm{~min}$, the cells were stained consecutively with the first antibodies, second antibodies, and DAPI $(1 \mu \mathrm{g} / \mathrm{ml})$ for 3 $\mathrm{hr}, 1 \mathrm{hr}$, and $5 \mathrm{~min}$, respectively. The first antibodies used were affinity-purified MCM2 $(1: 5)$ or MCM3 $(1: 100)$ antibody together with rat anti- $\alpha$ tubulin antibody YOL1/34 [1:500; kindly provided by Dr. Tim Huffaker; (Kilmartin et al. 1982)] in the Western buffer containing $1 \%$ dry milk. Fluorescein-conjugated goat anti-rabbit antibody $(1: 80)$ and rhodamine-conjugated goat anti-rat antibody $(1: 500)$ were used as the second antibodies.

\section{Nuclear fractionation}

Nuclear fractionation was done essentially according to Goto et al. (1982). Yeast cells were harvested and resuspended in the digestion mixture $(100 \mathrm{mg} / \mathrm{ml}$ of Zymolyase T100, $1 \mathrm{M}$ sorbitol, $0.5 \mathrm{mM} \mathrm{CaCl}_{2}$, and $0.5 \% \beta$-mercaptoethanol in YEPD|. After 30 min digestion at $37^{\circ} \mathrm{C}$, the spheroplasts were spun down at 2400 $g$ for $5 \mathrm{~min}$, resuspended in the lysis buffer $(18 \%$ Ficoll, $20 \mathrm{~mm}$ potassium phosphate $(\mathrm{pH} 6.8), 0.5 \mathrm{mM} \mathrm{CaCl}_{2}, 0.5 \% \beta$-mercaptoethanol, and $1 / 1000$ dilution of the protease cocktail [100 mM PMSF in ethanol; $50 \mathrm{mM} N$-tosyl-L-phenylalanine chloromethyl ketone (TPCK), $5 \mathrm{mM} \mathrm{N} \alpha$-p-tosyl-1-lysine chloromethyl ketone (TLCK) in methanol; and $2 \mathrm{mg} / \mathrm{ml}$ of pepstatin A in $1: 1$ ( $\mathrm{vol} /$ vol) methanol/water], and lysed by $20 \times$ Dounce homogenization (pestle A). Unlysed cells were removed by centrifugation at $5500 \mathrm{~g}$ for $5 \mathrm{~min}$. The lysate (total fraction) was centrifuged further at $30,000 \mathrm{~g}$ for $25 \mathrm{~min}$ to generate a pellet (nuclear fraction) and a supernatant (cytoplasmic fraction). The three fractions were adjusted to the same volume to allow quantitative comparison.

\section{Subnuclear fractionation}

Nuclei were resuspended in the extraction buffer $[\mathrm{CE} ; 10 \mathrm{mM}$ HEPES (pH 7.5), $1 \mathrm{~mm}$ EDTA, $10 \mathrm{~mm} \mathrm{NaCl}$ (Campbell and Duffus 1988) containing different concentrations of $\mathrm{NaCl}$, incubated on ice for $10 \mathrm{~min}$, and spun in a microcentrifuge at 12,000 $\mathrm{rpm}$ for $10 \mathrm{~min}$. The supernatant (nucleoplasmic fraction) and the pellet (nuclear pellet) were normalized to equal volume for quantitative comparison. The nuclear pellet derived from the CE buffer extraction was fractionated further as follows. It was resuspended in buffer SE [10 mM Tris- $\mathrm{HCl}$ (pH 7.5], $290 \mathrm{mM}$ sucrose, $0.1 \mathrm{mM} \mathrm{MgCl}_{2}$ ] supplemented with DNasel (GIBCO $\mathrm{BRL}$ ) and $1 \mathrm{~mm}$ DTT, or RNase A (Sigma), or NP-40 (Sigma), incubated at $37^{\circ} \mathrm{C}$ for $10 \mathrm{~min}$, and spun in a microcentrifuge at $12,000 \mathrm{rpm}$ for $10 \mathrm{~min}$. The pellets were adjusted to the same volume as the supernatant for analysis.

\section{Acknowledgments}

This work would not have been possible without the MCM3specific antiserum prepared by Susan Gibson. The help of Shlomo Eisenberg, Scott Greenfeder, and Joel Huberman in twodimensional gel technology is gratefully acknowledged. We thank Tim Huffaker for advice and use of his fluorescence microscope. We are indebted to Michael Grunstein for providing the histone $\mathrm{H} 2 \mathrm{~B}$-specific antiserum. This work was supported by National Institutes of Health grant GM34190.

The publication costs of this article were defrayed in part by payment of page charges. This article must therefore be hereby marked "advertisement" in accordance with 18 USC section 1734 solely to indicate this fact.

\section{References}

Blow, J.J. and R.A. Laskey. 1988. A role for the nuclear envelope in controlling DNA replication within the cell cycle. Nature 332: 546-548.

Boeke, J.D., F. LaCroute, and G. R. Fink. 1984. A positive selection for mutants lacking orotidine-5'-phosphate decarboxylase activity in yeast: 5 -fluoro-orotic acid resistance. Mol. Gen. Genet. 197: 345-346.

Brewer, B.J. and W.L. Fangman. 1987. The localization of replication origins on ARS plasmids in S. cerevisiae. Cell 51: 463-471.

Burton, D.R., M.J. Butler, J.E. Hyde, D. Philips, C.J. Skidmore, and I.O. Walker. 1978. The interaction of core histones with DNA: Equilibrium binding studies. Nucleic Acids Res. 5: 3643-3663.

Campbell, I. and J.H. Duffus. 1988. Yeast: A practical approach. IRL Press, Oxford, UK. 
Chen, Y., K.M. Hennessy, D. Botstein, and B.K. Tye. 1992. CDC46/MCM5, a yeast protein whose subcellular localization is cell-cycle regulated, is involved in DNA replication at ARSs. Proc. Natl. Acad. Sci. 89: 10459-10463.

Coxon, A., K. Maundrell, and S. Kearsey. 1992. Fission yeast $c d c 21^{+}$belongs to a family of proteins involved in an early step of chromosome replication. Nucleic Acids Res. 20: $5571-5577$.

Dasso, M. and J.W. Newport. 1990. Completion of DNA replication is monitored by a feedback system that controls the initiation of mitosis in vitro: Studies in Xenopus. Cell 61: 811-823.

Dieckmann, C.L. and A. Tzagoloff. 1985. Assembly of the mitochondrial membrane system. $C B P 6$, a yeast nuclear gene necessary for synthesis of cytochrome b. I. Biol. Chem. 260: 1513-1520.

D'Urso, G., R.L. Marraccino, D.R. Marshak, and J.M. Roberts. 1990. Cell cycle control of DNA replication by a homologue from human cells of the $\mathrm{p} 34^{\text {cdc2 }}$ protein kinase. Science 250: 786-791.

Elble, R. and B.K. Tye. 1992. Chromosome loss, hyperrecombination, and cell cycle arrest in a yeast $\mathrm{mcm} 1$ mutant. $M o l$. Biol. Cell. 3: 971-980.

Feinberg, A.P. and B. Vogelstein. 1983. A technique for radiolabeling DNA restriction endonuclease fragments to high specific activity. Anal. Biochem. 132: 6-13.

Ferguson, B.M., B.J. Brewer, A.E. Reynolds, and W.L. Fangman. 1991. A yeast origin of replication is activated late in $S$ phase. Cell 65: 507-515.

Gibson, S.I. 1989. "Analysis of $m \mathrm{~cm} 3$, a minichromosome maintenance mutant of yeast with a cell division cycle arrest phenotype." Ph.D. thesis, Cornell University, Ithaca, NY.

Gibson, S.I., R.T. Surosky, and B.K. Tye. 1990. The phenotype of the minichromosome mutant $\mathrm{mcm} 3$ is characteristic of $\mathrm{mu}$ tants defective in DNA replication. Mol. Cell. Biol. 10: 5707-5720.

Goto, T., P. Laipis, and J. C. Wang. 1982. The purification and characterization of DNA topoisomerase I and II of the yeast Saccharomyces cerevisiae. J. Biol. Chem. 259: 10422-10429.

Harlow, E. and D. Lane. 1988. Antibodies: A laboratory manual. Cold Spring Harbor Laboratory, Cold Spring Harbor, New York.

Hartwell, L.H. 1976. Sequential function of gene products relative to DNA synthesis in the yeast cell cycle. I. Mol. Biol. 104: 803-817.

Hennessy, K.M., C.D. Clark, and D. Botstein. 1990. Subcellular localization of yeast Cdc46 varies with the cell cycle. Genes \& Dev. 4: 2252-2263.

Hennessy, K.M., A. Lee, E. Chen, and D. Botstein. 1991. A group of interacting yeast DNA replication genes. Genes \& Dev. 5: 958-969.

Hereford, L.M., and L.H. Hartwell. 1974. Sequential gene function in the initation of Saccharomyces cerevisiae DNA synthesis. J. Mol. Biol. 84: 445-461.

Huberman, J.A., J. Zhu, L.R. Davis, and C.S. Newlon. 1988. Close association of a DNA replication origin and an ARS element on chromosome III of the yeast Saccharomyces cer. evisiae. Nucleic Acids Res. 16: 6373-6384.

Hunkapiller, M.W., E. Lujan, F. Ostrander, and L.E. Hood. 1983 Isolation of microgram quantities of proteins from polyacrylamide gels for amino acid sequence analysis. Methods Enzymol. 91: 227-236.

Kilmartin, J.V. and A.E.M. Adams. 1984. Structural rearrangements of tubulin and actin during the cell cycle of the yeast Saccharomyces. I. Cell Biol. 98: 922-933.

Kilmartin, J.V., B. Wright, and C. Milstein. 1982. Rat monoclo- nal anti-tubulin antibodies derived by using a new nonsecreting rat cell line. I. Cell Biol. 93: 576-582.

Linskens, M.H.K. and J.A. Huberman. 1989. Ambiguities in results obtained with $2 \mathrm{D}$ gel replicon mapping techniques. Nucleic Acids Res. 18: 647-652.

Maine, G.T., P. Sinha, and B.-K. Tye. 1984. Mutants of S. cerevisiae defective in the maintenance of minichromosomes. Genetics 106: 365-385.

Moir, D., S.E. Stewart, B.C. Osmond, and D. Botstein. 1982 Cold-sensitive cell-division-cycle mutants of yeast: Isolation, properties, and pseudoreversion studies. Genetics 100: $547-563$.

Moll, T., G. Tebb, U. Surana, H. Bobitsch, and K. Nasmyth. 1991. The role of phophorylation and the CDC28 protein kinase in cell cycle-regulated nuclear import of the $S$. cerevisiae transcription factor SWI5. Cell 66: 743-758.

Pringle, J.R. and L.H. Hartwell. 1981. The Saccharomyces cerevisiae cell cycle. In The molecular biology of the yeast Saccharomyces J.N. Strathern, E.W. Jones, and J.R. Broach, pp. 79-142. Cold Spring Harbor Laboratory, Cold Spring Harbor, NY.

Rao, P.N. and R.N. Johnson. 1970. Mammalian cell fusion: Studies on the regulation of DNA synthesis and mitosis Nature 225: 159-164.

Ruther, U. and B. Muller-Hill. 1983. Easy identification of cDNA clones. EMBO /. 2: 1791-1794.

Sinha, P., V. Chang, and B.K. Tye. 1986. A mutant that affects the function of autonomously replicating sequences in yeast. J. Mol. Biol. 192: 805-814.

Smythe, C. and J.W. Newport. 1992. Coupling of mitosis to the completion of $\mathrm{S}$ phase in Xenopus occurs via modulation of the tyrosine kinase that phosphorylates $\mathrm{p} 34^{\mathrm{cdc} 2}$. Cell 68: 787-798.

Thommes, P., R. Fett, B. Schray, R. Burkhart, M. Barnes, C. Kennedy, N. Brown, and R. Knippers. 1992. Properties of the nuclear P1 protein, a mammalian homologue of the yeast Mcm3 replication protein. Nucleic Acids Res. 20: 10691074.

Vaitukaitis, J.L. 1981. Production of antisera with small doses of immunogen: Multiple intradermal injections. Methods Enzymol. 73: 46-52.

Walker, S.S., A.K. Malik, and S. Eisenberg. 1992. Analysis of the interactions of functional domains of a nuclear origin of replication from Saccharomyces cerevisiae. Nucleic Acids Res. 19: 6255-6262.

Weinert, T.A. and L.H. Hartwell. 1988. The RAD9 gene controls the cell cycle response to DNA damage in Saccharomyces cerevisiae. Science 241: 317-322.

Yan, H., S. Gibson, and B.K. Tye. 1991. Mcm2 and Mcm3, two proteins important for ARS activity, are related in structure and function. Genes \& Dev, 5: 944-957. 




\section{Cell cycle-regulated nuclear localization of MCM2 and MCM3, which are required for the initiation of DNA synthesis at chromosomal replication origins in yeast.}

$\mathrm{H}$ Yan, A M Merchant and B K Tye

Genes Dev. 1993, 7:

Access the most recent version at doi:10.1101/gad.7.11.2149

References This article cites 35 articles, 13 of which can be accessed free at:

http://genesdev.cshlp.org/content/7/11/2149.full.html\#ref-list-1

License

Email Alerting Service

Receive free email alerts when new articles cite this article - sign up in the box at the top right corner of the article or click here.

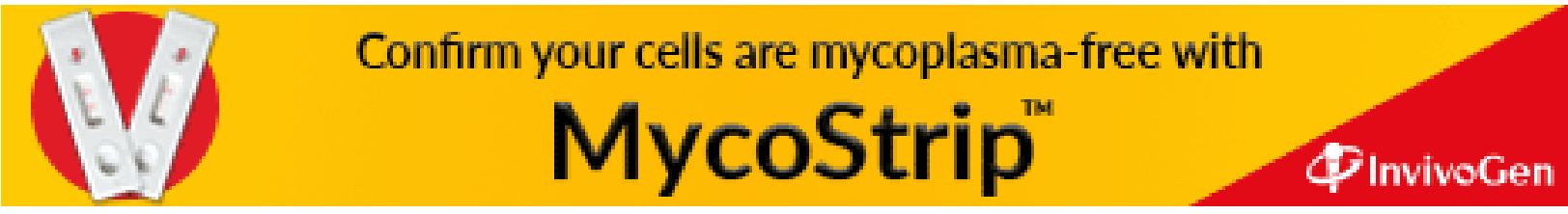

